\title{
Land Reallocation Reform in Rural China: A Behavioral Economics Perspective
}

\begin{abstract}
Based on prospect theory, we develop a theoretical framework to unify divided views on land reallocation reform in China. Our theoretical framework and empirical verification explain the driving forces behind the success of the rural land reallocation reform in China. We find that rural land reallocation reform in China is characterized by induced and imposed institutional changes. The relationship between induced and imposed institutional change is complementary instead of competing. The decision and frequency of land reallocation are affected by both local endowment and central government policy. Empirical findings also suggest that land reallocation reform in China is incremental, with interim policy targets from different stages taking gradual effect. The incremental implementation of the "No Reallocation" policy is the reason behind the widespread, diversified land reallocation practices across the country; this policy also contributes to the success of rural land reform in China. The theoretical model can be used to study a wide range of government-led institutional changes in China, such as affordable housing schemes and the National New-type Urbanization Plan (2014-2020).
\end{abstract}

Keywords: Land reallocations; Induced and imposed institutional change; Prospect theory; Land market in China. 


\section{Introduction}

Rural land market reform in China can be traced back to the introduction of the Household Responsibility System in the late 1970s. After three decades of market reform and urbanization, $36.3 \%$ of Chinese still lives in rural areas ${ }^{1}$, which account for over $70 \%$ of the total land area in China; the agricultural sector contributes only $10 \%$ to the national GDP (National Bureau of Statistics, 2014). The proportion of rural population is still well above developed nations' average of $20 \%$. As revealed in the nation's first urbanization plan in March 2014, China will speed up the country's urbanization process to foster sustainable and healthy economic growth. Rural sector plays an important role in this challenging undertaking. Theories of development economics suggest that agricultural growth is crucial for industrialization and economic development (see e.g., Schultz, 1964; Hayami \& Ruttan, 1971). Improving productivity in rural China is of great importance for food security and the national economy. To achieve this goal, one of the most effective tools is granting land-use rights and residual income rights to rural households (Lin, 1992; de Soto, 2000).

In rural China, arable lands are jointly owned by groups of rural residents in the same village. The term "collective" is coined for such groups of rural households. Under a collectively owned land right system, a piece of land on per capita basis is allocated to each villager. Payoff for individuals is determined not by their own productivity, but by the overall productivity of their collective. Specifically, output from individuals are pooled first and then equally distributed among all members of the collective. Collectivization achieves the ideological goal of equal access to land. However, the system is inefficient because villagers are not provided enough incentives to contribute to the collective and their motivation to free-ride is strong (see e.g., Kojima, 1988; Kochin, 1996). In the late 1970s, the Household Responsibility System emerged quietly through experiments by villagers who were supported by their local governments. The System essentially gave villagers the right to retain residual income from lands allocated to them and marked the start of the Decollectivization Reform (Diamond, 1985).

Decollectivization is one of the most important institutional changes in the history of modern China because it fundamentally altered the land-use rights system in rural China and significantly improved agricultural productivity (see e.g., Nolan, 1983; Kojima, 1988; Lin, 1992; Gaynor \& Putterman, 1993; Li et al., 1998; Deininger \& Jin, 2003). It also fueled the industrialization and urbanization processes by moving surplus rural labor force to other sectors (Lin, 1992; Binswanger, et al., 1995).

\footnotetext{
1 This figure includes residents who actually live in rural areas only. Unregistered migrant works (18\% of the total population by the end of 2013) that live in urban areas are not included. Unregistered urban residents do not have access to basic urban public services such as education, medical care, and pensions.
} 
Empirical evidence shows that employment share in the agricultural sector dropped by almost $50 \%$ from 1978 to 2007 while productivity growth rate outperformed all other sectors for most of this period (Zhu, 2012, Table 2, pp. 111). The success of the Household Responsibility System was celebrated by the public and formally recognized by the central government (See Ash, 1988 for a chronological account of the agricultural reform in China). The next challenge in Decollectivization Reform is to adjust the system so it can keep up with the rapid urbanization and economic reform in China, an objective that can mainly be achieved through land reallocation reform.

In decollectivization, the land is still collectively owned. Although the exchange of land-use rights was endorsed by the central government in 1984, the rural land rental market was only formally established in 2002 when the Rural Land Contract Law was passed by Congress. The development of the rural land rental market (i.e., rural land-use rights exchange market) has been slow. Land reallocation remains the only effective way of adjusting land allocation to meet demographic changes and economic development in rural China (see e.g., Kung, 1995 \& 2000; Liu et al., 1998; Benjamin \& Brandt, 2002). Broadly speaking, land reallocation has two types. A full reallocation (da tiaozheng) takes back all or most land holdings and redistributes them among all households in the collective. A partial reallocation (xiao tiaozheng) only involves land holdings and households affected by demographic changes. Understandably, full reallocations are less frequent than partial reallocations in practice because it is associated with a greater level of land rights insecurity.

Determining the frequency and scale of land reallocation is a delicate issue (Wang et al., 2011). Land-use rights should be granted to households for a sufficiently long period of time to justify long-term investment in land holdings. Frequent and/or large-scale reallocation results in tenure insecurity, and consequently discourages investment in land holdings (Li et al., 1998; Brandt et al., 2002; Jacoby et al., 2002). By contrast, rapid urbanization in China causes fast demographic changes in rural China (Cai \& Wang, 2010; Peng, 2011). Timely reallocation is necessary to address resource mismatch and ensure equal access to farmland by all members of collectives. How can tenure security and land-use efficiency be balanced? What is the driving force of land reallocation? These important questions cannot be answered without understanding the dynamics between the local and central governments in land reallocation.

Lin (1989) claims that institutional change can be broadly classified into two categories. The first one, induced institutional change, is usually initiated by and experimented in private sectors and adopted by the government after being proved successful. The second type, imposed institutional change, is prescribed top-down by the state and is often associated with drastic social, economic, or legal adjustments. The difference between these two types of institutional change rests in involved political and economic risks. Induced institutional change is allowed or even 
encouraged by the central government when the reform involves low political risk and significant economic gains, whereas imposed institutional change is preferred for decisions that may cause substantial political loss but great economic uncertainty (Zhang, 2012). Consequently the payoffs must be sufficiently large to justify imposed institutional changes such that the expected gains can outweigh the expected costs. Imposed institutional changes are also necessary when parties with conflicting interests are involved. Without such top-down interventions the supply of institutional changes might not be sufficient due to rent-seeking behaviors and free-rider issues (Lin, 1989; North, 1990; Lin \& Nugent, 1995).

According to this framework, the Decollectivization Reform started as induced institutional change. The Household Responsibility System was first experimented with in remote and disadvantaged villages in China, where the stake of failure is low. The success of the System later ignited nationwide adaptation and led to the formal reorganization by the state. However, the nature of the current stage of decollectivization (i.e., land reallocation reform) is still open for debate. If left unsupervised, land reallocation is likely to pose a serious threat to tenure security and discourage farmland investment. Therefore, state intervention is inevitable. One would expect that both imposed and induced institutional changes are in force. However, empirical evidence suggests that state intervention is ineffective.

First, stylized evidence shows that the goals of the local and central governments do not align. For example, Deininger and Jin (2009) find that almost 30\% of the villages surveyed in their study have undergone land reallocation since 2000. However, as early as in 1984, the state has stipulated that land-use rights should be contracted to villagers for a minimum of 15 years, which was extended to 30 years in 1993. Land-use rights are taken back from villagers before the end of their contract when lands are reallocated, which negatively affects tenure security, farmland investment, and agricultural productivity. A "persistence of seemingly inefficient institutions" is at work (Kung \& Bai, 2011). This condition is in stark contrast to the "federalism with political centralization" model, where the local government is given incentives and the freedom to foster economic growth while the central government maintains a strong and disciplined control by rewarding or punishing local administrations (Blanchard \& Shleifer, 2001). This model is recognized as the key success factor of the economic growth of China (Blanchard \& Shleifer, 2001; Xu, 2011). However, it does not seem to work for land reallocation reform. Land reallocation rules laid out by the central government are duly ignored by local governments.

The academia also pays little attention to the role of the government. Most studies on land reallocation are based on the induced institutional change hypothesis (see e.g., Brandt et al., 2004; Yao, 2004a \& 2004b; Kung \& Bai, 2011; Wang et al., 2011), and the results are mixed. Some empirical evidence supports the induced institutional change hypothesis (Yao, 2004a \& 2004b), but other studies favor the transaction cost 
hypothesis (Kung \& Bai 2011) ${ }^{2}$. Brandt et al. (2004) find rent-seeking behaviors and the duty of village leaders to meet tax and quota obligations as the most important reasons to reallocate land. They conclude that the best way to enhance rural land tenure security is to change the incentives for village leaders. The theoretical framework and empirical findings from these studies provide valuable insight into rural land reallocation reform in China. However, the role of state intervention hardly has any evidence. Some researchers justify this approach by stating that the policies of the central government are simply ignored by local authorities (see e.g., Brandt et al., 2004, pp. 629). Others choose to seek alternative economic justifications for this apparent inefficiency, such as the transaction costs hypothesis tested in Kung and Bai (2011). The role of state intervention is discussed in some studies (see e.g., Deininger \& Jin, 2009) but never formally incorporated in the theoretical framework of any of the studies. This approach is convenient for establishing econometric models, but at the expense of overlooking national policy as an important determinant of institutional changes.

The objective of this paper is to develop a theoretical framework to bridge this gap. We start with the model of Lin (1989) by considering induced and imposed institutional changes as the driving forces in land reallocation reform in China. We argue that the relationship between the two forces is complementary. At a different stage of economic reform, one force may be more effective than the other. However, neither one ceases affecting rural land reform at any stage. We revise and extend Lin's (1989) model in two ways. First, we adopt the revised definition of induced institutional change proposed by Zhang (2012) to establish a clear and logical link between the two types of institutional changes. Second, we adopt prospect theory (PT) (Kahneman \& Tversky, 1979) to model the dynamics between induced and imposed institutional changes. This adoption leads to the construction of a model that links all stakeholders involved in land reallocation. The theoretical framework is examined using a unique dataset collected from a longitudinal village survey in 17 Chinese provinces from 1999 to $2010^{3}$. We conclude that rural land reallocation reform in China is driven by both induced and imposed institutional changes. Our theoretical framework and empirical verification explain the driving forces behind the success of the rural land reallocation reform in China. The success of the reform largely contributes to the incremental approach realized by a combination of induced and imposed institutional changes. The findings offer empirical support to property rights economics and institutional change theories (see, for example, Lin, 1989; North, 1990; de Soto, 2000). The theoretical model can be used to study a wide range of government-led institutional changes in China, such as affordable housing schemes and the National New-type Urbanization Plan (2014-2020).

\footnotetext{
2 Transaction cost theory and induced institutional change theory are closely related. Reducing transaction cost is one of the important considerations in induced institutional change theory. Whether their relationship is complementary or substitutive is still open to debate.

${ }^{3}$ Based on five surveys conducted by Renmin University of China (RUC) and Rural Development Institute (RDI) in the US.
} 
The remainder of the paper is organized as follows. The development of the theoretical framework and testable hypotheses are given in Section 2, followed by the descriptions of data and survey background information in Section 3. Empirical evidence and discussions are presented in Section 4 and Section 5. The conclusions are presented in Section 6.

\section{Theoretical Framework and Testable Hypotheses}

Lin (1989) claims that induced institutional change is "a modification or replacement of an existing institutional arrangement or the emergence of a new institutional arrangement that is voluntarily initiated, organized, and executed by an individual or a group of individuals in response to profitable opportunities," whereas an imposed change is "introduced and executed by governmental orders or laws." Zhang (2012) states that imposed institutional changes are associated with uncertain economic gains and high political risk, whereas induced institutional changes tend to prevail in domains where economic gains are more certain and political loss is limited. Zhang (2012) revises the definition of induced institutional change by Lin (1989) by recognizing that "the central government collects information as to which institutional change will most likely be a certain success." The information is then used in the design and implementation of central government policies (i.e., imposed institutional changes). The central government is involved in induced institutional change by creating and utilizing a feedback system between the two types of institutional changes. We adopt the definition of Zhang (2012) as it has sound micro-foundations, especially in the context of the rural land reallocation reform of China. Without losing any generality, we define induced institutional changes as changes mainly driven by the local government ${ }^{4}$, whereas imposed changes are driven by the central government ${ }^{5}$. This definition is different from the "mutually exclusive" approach introduced by Lin (1989) and his followers, where induced and imposed institutional changes are often used as competing theories to explain economic and political reforms in China. Researchers draw a fine line between the two types of change; institutional changes are classified as either induced or imposed ${ }^{6}$. This classification is a valid approach for institutional changes that do not require the endorsement of the central government (and can thus be "induced" by private sectors) or cannot happen

\footnotetext{
${ }^{4}$ We adopt a broad definition of local government in this study. In China, the local government has various levels: village, township, city, or provincial government. Our definition of local government does not differentiate among these levels.

${ }^{5}$ After 30 years of political and economical reforms, local governments in China are significantly decentralized and competitive among each other. Their completion to achieve GDP growth, fiscal income maximization and promotion is similar to effective competitions among private enterprises (a comprehensive review of related studies on rural local government in China can be found in Smith, 2013). Therefore these local governments can not only initiate institutional changes, but also be actively involved in imposed institutional changes initiated by the central government.

${ }^{6}$ See the discussion in Zhang, 2012 on the differences between Household Responsibility System and Special Economic Zones for example.
} 
without the initiative of the central government (and must thus be "imposed" from the top). For example, the setup of Special Economic Zones is an imposed institutional change because all special taxation and trade advantages a special economic zone can enjoy must be defined and enforced by the central government. The local government and private sectors cannot initiate such a change even in an experimental setting.

This framework needs fine-tuning with regard to land reallocation reform. The relationship between induced and imposed institutional changes is complementary, instead of contradictory. This relationship is determined by the nature of land reallocation. Arable land reallocation is essentially the redistribution of the most important natural resource in rural China. It has significant impact on agricultural productivity, food security, national economy, and social stability, to name a few. The outcome of any institutional change in this domain must be politically correct, but the economic payoff is inherently uncertain. Hence, institutional change should not be initiated by private entities and/or the local government, but should be imposed from the top by the central government. Nevertheless, land reallocation is also heavily influenced by the social, economic, demographic, and natural endowment composition in each locality. For example, villages with high population density and mobility need more frequent land reallocation to keep up with the changes in population and labor composition. As Chinese villages are greatly heterogeneous in these aspects, radical land reallocation reform is likely to create and/or widen gaps between villages as well as cause deep political and economic losses. Considering the local endowment and status quo and allowing the local governments to "set their own pace" in land reallocation reform are important. The central government must set achievable interim milestones for the local governments to reach their final targets. This process is depicted in Figure 1.

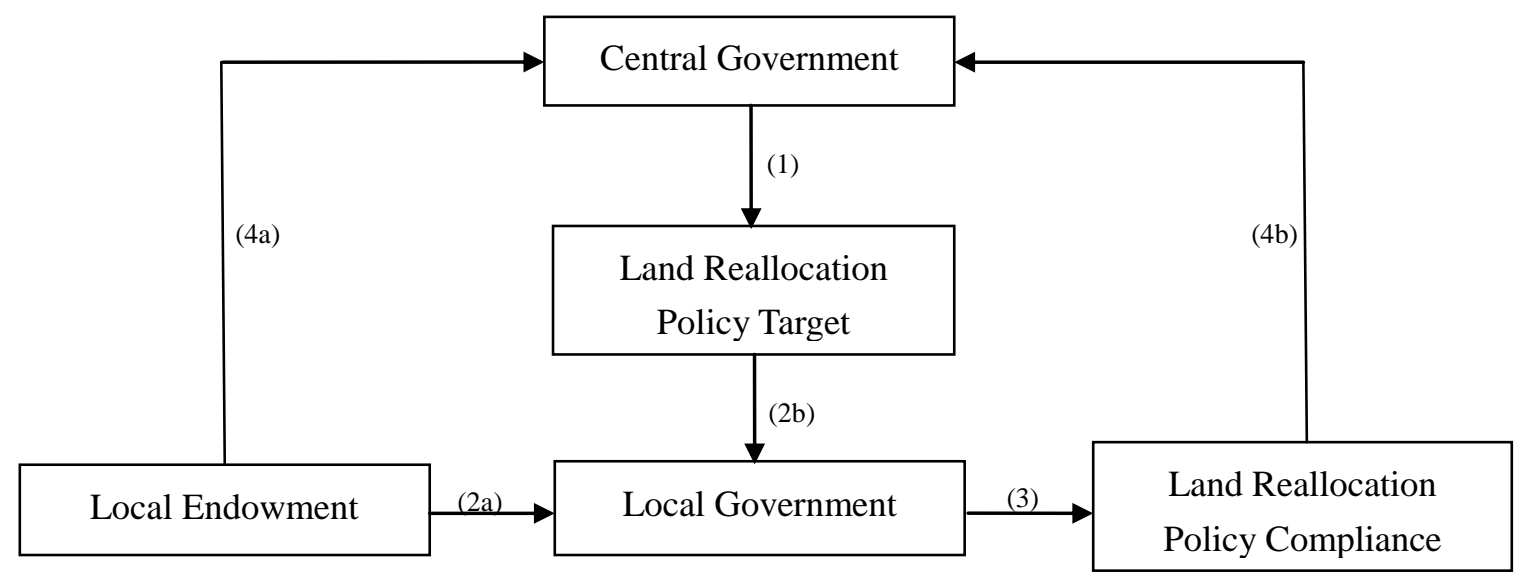

Figure 1: Decision-making Process

Figure 1 illustrates the decision-making process for land reallocation reform. Four steps are involved in this process. The central government starts the process by setting a national-level target. The central policy influences the behaviors of the local government (Step 2b). The local government also needs to consider local endowment 
to decide whether and to what extent to comply with the new policy of the central government (Step 2a). The combined effects of Steps 2a and 2b lead to a certain level of policy compliance (Step 3). The key is that the process does not end here. The target set in Step 1 is not the final target but an interim one because localities are heterogeneous in natural endowment and the current level of land reallocation policy compliance. If local diversity is overlooked and the target is set at the highest level (i.e., a one-off radical reform), then some local governments may find the goal unrealistic to achieve and lose motivation to comply. The central government sets achievable targets by stages. The objective is to motivate worse-off local governments to improve over time, reduce local variation, and eventually reach the final policy target. To achieve this, Steps $4 \mathrm{a}$ and $4 \mathrm{~b}$ are crucial because they are essential feedback links in this process. The central government studies local endowment and the current level of land reallocation policy compliance in local governments to decide how to set the target for the next stage, where a new circle begins with Step 1.

Figure 1 shows how induced and imposed institutional changes are integrated in the land-use policy making of China. Step 2a is the link for induced institutional change, by which the decisions of the local government are influenced by natural endowment. By contrast, Step $2 b$ reflects the effect of the central government on the decision making of the local government, which is the effect of imposed institutional change. Steps $4 \mathrm{a}$ and $4 \mathrm{~b}$ demonstrate the link between imposed and induced institutional changes. As the last steps in decision-making stage $t$, Steps $4 \mathrm{a}$ and $4 \mathrm{~b}$ lead to the first step in decision-making stage $t+1$, which is an ongoing process with feedback from the local to the central government.

To date, extensive research has been done on Step 2a. Existing studies mainly focus on the induced institutional change aspect of the land market of China. Imposed institutional change or the role of central government (Step 2b) is largely overlooked. No evidence supports the validity of Steps $4 \mathrm{a}$ and $4 \mathrm{~b}$. To bridge this gap in the literature, we propose a theoretical framework to model the dynamics in land reallocation between the local and central governments. The framework is based on PT (Kahneman \& Tversky, 1979).

Different from standard economic theory, PT uses value function instead of utility function. The essence of PT is reference dependence, loss aversion, and diminishing sensitivity (Tversky \& Kahneman, 1991). Specifically, an individual determines the changes of wealth/endowment by comparing the current level with a reference point, which divides the value space into a Gain Realm and a Loss Realm (Figure 2a). The outcome is classified as either gains (i.e., current level > reference point level) or losses (i.e., current level < reference point level). The value function is steeper for losses than for gains. Moreover, the value function is convex in the Gain Realm and concave in the Loss Realm. These characteristics can be expressed as follows: 
$\mathrm{V}(\mathrm{X})= \begin{cases}(X-r)^{\alpha} & \text { if } X \geq r \\ -\beta(r-X)^{\alpha} & \text { if } X<r\end{cases}$

where $\mathrm{V}(\mathrm{X})$ is the value function of $X, r$ is the reference point that takes non-zero values (i.e., reference dependence), $\alpha<1$ (i.e., diminishing sensitivity), and $\beta>1$ (i.e., loss aversion).

In the last three decades, PT has been applied in a wide range of topics, including management (Goldfarb et al., 2012), finance (Barberis, 2013), social and transport sciences (van de Kaa, 2010), and other economic problems (DellaVigna, 2009). PT gained popularity in various fields because it offers a formal framework to incorporate preference (i.e., reference point) in the decision-making at all levels. Under PT, individuals and institutions are heterogeneous in their preference and motivated differently when facing the same decision. PT is a convenient model when taking into account motivation and incentive in decision-making. It has a great potential for application in political sciences (Wilson, 2011). However, to date, Zhang (2012) remains the first and only attempt in applying PT in institutional changes in China. This paper extends Zhang's (2012) work by incorporating both imposed and induced institutional change in the same framework.

Analyzing the decision-making behavior of the local government starts with defining and analyzing its value function. Figure $2 b$ is the value function for the local government in terms of compliance with land reallocation policy. $\mathrm{X}$ is the current level of policy compliance. Value function for the local government measures political outcome, such as promotion ${ }^{7}$. It is determined by the difference between the level of compliance with the current land-use policy and the target set by the central government. The following assumptions are made about the value function of the local government:

\footnotetext{
${ }^{7}$ Promotion can be either direct promotion to posts in higher-level governments (Blanchard \& Shleifer, 2001) or indirect promotion through higher GDP performance and local fiscal benefits (Montinola et al., 1995; Jin et al., 2005).
} 


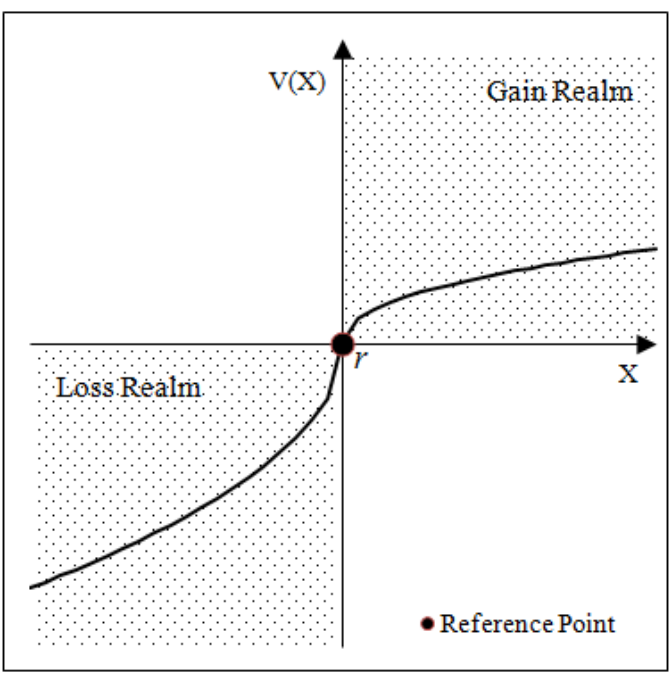

a) Standard model

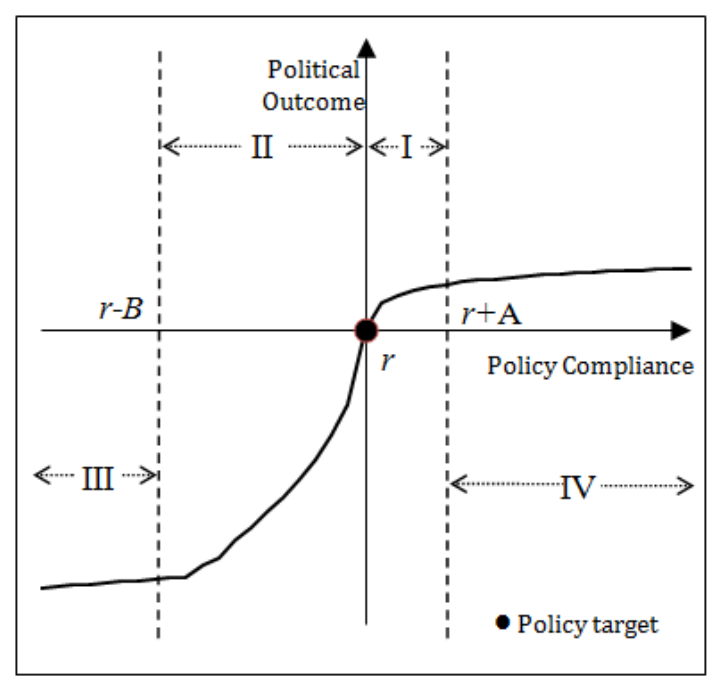

b) Application in land reallocations in China

Figure 2: Value Functions

\section{A1: The value function flats out rapidly in the Gain Realm.}

Local governments in the Gain Realm are outperforming because their current level of policy compliance is above the target. Their political payoff is an increasing function of further improvement but flats out quickly after point $r+A$ because the effort to outperform the target level is often not recognized formally or the political payoff is uncertain. In response, the local government is not motivated to outperform significantly. In Figure 2b, the Gain Realm is divided into Zones I and IV by point $r+A$. In Zone I, the local government is motivated to improve compliance with the land reallocation policy (i.e., to move to the right along the horizontal axis) to generate more political gains (i.e., the value function will increase). However, the local government quickly becomes reluctant to improve further because extra effort does not lead to much increase in political outcome. This region is marked as Zone IV in Figure 2b. A essentially captures the maximum amount of extra effort that an over-performing local government is willing to make and determines the width of Zone I.

\section{A2: The value function is steeper in the Loss Realm and flats out eventually.}

The political implication of performing below a standard set by the central government does not need to be spelled out. If a local government finds its initial position is in the Loss Realm, the motivation to improve policy compliance (i.e., to move to the right along the horizontal axis) is high. The Loss Realm is also divided into two zones at point $r-B$. In Zone II, political outcome improves accordingly at an increasing rate as the local government improves its policy compliance. However, if the political outcome takes too long or too much effort to meet the target, the local government becomes less motivated to make much improvement because the political outcome is not reaped by the current governors during their term. The typical term of 
local officials is only five years, and the local government is assumed to be cautious in investing in projects to improve rights security that will take more than five years to show effects. As a result, the value function in Zone III flats out quickly after point $r$ - B. $B$ essentially captures the maximum amount of extra effort that an under-performing local government is willing to make and determines the width of Zone II.

Zones I and II are the effective zones. Local governments within these two zones are motivated to improve their policy compliance. Zones III and IV are ineffective zones in the sense that the presence of the policy target (or reference point) does not offer much motivation for improvement; local governments are better off doing the very minimum or nothing. Having local governments in Zone IV is often not a concern. Although non-doing is expected from this group, they still meet the current policy target. Moreover, being able to slow down local governments may serve the purpose of narrowing gaps between localities. Zone III causes trouble the most. Local governments within this zone are left demotivated and thus underperform further. In contrast, local governments in the effective zones continue improving their level of policy compliance, which results in polarization, an undesirable political outcome at both local and central government level.

\section{A3: All local governments share the same value function at a given time.}

All local governments are evaluated by the central government and affected by a single policy target that is set centrally. Thus, to assume that all local governments share the same value function is reasonable. Local governments treat the policy target set by the central government as the reference point in their value function; the reward/punishment for the same amount of improvement/underperformance is consistent for all localities.

Based on PT and under assumption A1 through A3, local governments adjust their level of policy compliance to maximize the following value function:

$$
V\left(X_{i, t}\right)=\left\{\begin{array}{cl}
A^{\alpha} & \text { if } X_{i, t} \geq r_{t}+A \\
\left(X_{i, t}-r_{t}\right)^{\alpha} & \text { if } r_{t} \leq X_{i, t}<r_{t}+A \\
-\beta\left(r_{t}-X_{i, t}\right)^{\alpha} & \text { if } r_{t}-B<X_{i, t}<r_{t} \\
-\beta B^{\alpha} & \text { if } X_{i, t} \leq r_{t}-B
\end{array}\right.
$$

where $X_{i, t}$ is the current level of policy compliance for local government $i$ at time period $t$, and $r_{t}$ is the reference point at time $t . A$ and $B$ are defined above. Note that Equation 2 allows reference points to vary over time but remains constant among local governments. The width of the effective zones, which is determined by the shape of the value function, is the same for all local governments and assumed to be constant over time. The assumption is reasonable because it reflects the consistency of 
the assessment scheme of the central government.

Under A1 through A3, whether a local government is located in the effective zones $\left[r_{t}-B, r_{t}+A\right]$ depends solely on the policy target set by the central government at time $t$ (i.e., $r_{t}$ ). Therefore, setting the policy at the correct level such that most, if not all, local governments are within the effective zone is important for the central government. The process is illustrated in Figure 3. If a radical approach is adopted for land reallocation reform (see Figure 3a), the final target level for the central government is $R$, and the current target level is set at the final level (i.e., $r_{t}=R$ ). Without losing any generality, we assume that the goal of the central government is $E\left(X_{i, t+T}\right)=R$ and $\operatorname{Var}\left(X_{i, t+T}\right)=0$. In other words, all local governments meet the policy target in period $t+T$. However, a radical approach is likely to leave some local governments in Zone III if the current level of policy compliance $X_{i, t}$ of the local government has a large variation. As a result, $E\left(X_{i, t+T}\right) \approx E\left(X_{i, t}\right)$ for this underperforming group is below the final target level $R$, and $E\left(X_{i, t+T}\right) \approx R$ for local governments in other zones. Consequently, $E\left(X_{i, t+T}\right)<R$ and $\operatorname{Var}\left(X_{i, t+T}\right)$ is greater than $\operatorname{Var}\left(X_{i, t}\right)$ for the whole country at time $t+T$ because the distribution of the level of policy compliance is bimodal. When the overall level of policy compliance fails to meet the target, localities show greater dispersion.

If the central government adopts an incremental approach and sets attainable interim targets, including all local governments in Zones I, II, and IV is possible by setting $r_{t}-B \leq \min \left(X_{i, t}\right)$ or $r_{t} \leq \min \left(X_{i, t}\right)+B$. As illustrated in Figure $3 \mathrm{~b}$, the interim targets $\left(r_{t+1}, r_{t+2}\right.$, etc.) leave no local governments in the ineffective Zone III. Consequently, $E\left(X_{i, t}\right)$ is steadily moved toward $R$, and $\operatorname{Var}\left(X_{i, t}\right)$ is reduced. The goal of $E\left(X_{i, t+T}\right)=R$ and $\operatorname{Var}\left(X_{i, t+T}\right)=0$ is eventually achieved at time $t+T$.

To set the interim target $r_{t} \leq \min \left(X_{i, t}\right)+B$, the central government needs information about $X_{i, t}$ and $B$. As defined above, $B$ is determined mainly by how underperformance is punished by the central government and/or the general public, which is not difficult to predict as long as the central government sets the assessment scheme clearly and consistently. Any predictive errors are systematic and can be adjusted in the following period. $X_{i, t}$ is determined by both policy target level $\left(r_{t}\right)$ and the social, economic, and geographic characteristics of the locality within the same period; policy compliance outcome becomes a function of both induced and 
imposed institutional changes. The relationship is further illustrated in Equation 3 as follows:

$$
\left\{\begin{array}{l}
X_{i, t}=\alpha_{0}+\sum_{j=1}^{k} \alpha_{j} L_{i, j, t}+\beta r_{t}+\varepsilon_{i, t} \\
r_{t}=\gamma_{0}+\gamma_{1} X_{i, t-1}+\sum_{l=1}^{p} \theta_{l} Z_{i, l, t-1}+v_{i, t}
\end{array}\right.
$$

where $L_{i, j, t}$ is the $j^{\text {th }}$ local characteristics (e.g., population density and per capita GDP) for locality $i$ at time $t ; Z_{i, l, t}$ is the determining factor of $r_{t}$ other than $X_{i, t}, \alpha_{0}, \alpha_{j}, \beta, \gamma_{0}, \gamma_{1} ; \theta_{l}$ are parameters to be estimated; and $\varepsilon_{i, t}$ and $v_{i, t}$ are error terms. $\alpha_{j}(j=1,2, \ldots, k)$ captures the effect of Step 2(a) or induced institutional change effect in Figure 1. $\beta$ is the effect of imposed institutional changes or Step 2(b) in Figure 1. $\gamma_{1}$ reflects the endogenous nature of $r_{t}$, which means the central government considers the current level of policy compliance and endowment of the local government while setting the target for the next period. This system of equation captures the dynamics between induced and imposed institutional changes in the land reallocation reform of China. It is an incremental model, where the central government initiates and enforces interim targets that local governments are motivated to reach in several steps. The key to the success of this process is setting the targets or the reference points in PT term correctly. Land reallocation reform has no precedents, and localities are greatly heterogeneous in all possible aspects; thus, the central government has to give the local government room to adapt and experiment, which is the induced institutional change component of the process. The periodical outcome of these adaptation and/or experiment is observed and incorporated in the setting of targets for the next step, which is the imposed institutional change element of the reform. The relationship between induced and imposed institutional changes is complementary.

This framework is theoretically sound because the underlying PT model has not only been verified in many fields (see e.g., DellaVigna, 2009; Barberis, 2013), but also processes the three components required to study China reform as proposed by $\mathrm{Xu}$ (2011). Xu stresses that a valid theoretical framework for the study of China reform must recognize the uncertainty embedded in the process, the importance of local experiments, and the endogenous relationships among all parties involved. Our theoretical framework addresses all three issues by incorporating the participation of the local government and recognizing the endogenous nature of reference point formation under a PT framework.

Anecdotal evidence from China also supports our theoretical framework. Table 1 gives several policy milestones of land reallocation reform. The final goal of no land reallocation has been spelled out loudly and clearly since 1984, but the central government provided several flexible interpretations of the rules. For example, prior to 1996, both full and partial land reallocation are allowed under certain circumstances, whereas full reallocation is not allowed in the second stage 
(1997-2007). Essentially, land reallocation was not banned outright, but was gradually phased out by reducing both the scale and frequency of land reallocation over two decades. The flexible interpretation of rules often evolves from local practice, which proves induced institutional changes. Clearly imposed institutional changes (i.e., central government legislation and policy guidance) and induced institutional changes are integrated seamlessly in this process.

Table 1: Policy milestones of land reallocation reform in China (1984-2010) ${ }^{8}$

\begin{tabular}{|c|c|c|}
\hline Stage & Articles on land reallocation & Related policy documents \\
\hline $\begin{array}{c}\text { I (1984-1996): } \\
\text { Both partial } \\
\text { and full land } \\
\text { reallocations } \\
\text { were allowed. }\end{array}$ & $\begin{array}{l}\text { (1) Village collectives are allowed to } \\
\text { reallocate land through negotiations with } \\
\text { villagers. } \\
\text { (2) Reallocation is allowed in villages in } \\
\text { economically advanced regions and with a } \\
\text { small proportion of non-agricultural } \\
\text { workforce. }\end{array}$ & $\begin{array}{l}\text { (1) "Notice of the CPC Central } \\
\text { Committee on } 1984 \text { rural work" } \\
\text { ([1984] No. } 1 \text { document) } \\
\text { (2) "Policy measures on the current } \\
\text { agricultural and rural economic } \\
\text { development of the CPC Central } \\
\text { Committee and the State Council" } \\
\text { ([1993] No. 11 document) }\end{array}$ \\
\hline $\begin{array}{c}\text { II } \\
\text { (1997-2007): } \\
\text { Only partial } \\
\text { reallocations } \\
\text { were allowed. }\end{array}$ & $\begin{array}{l}\text { (1) Contracted land holdings are not } \\
\text { allowed to be reallocated unless due to } \\
\text { damages by natural calamities. } \\
\text { (2) Partial allocation is allowed if } \\
\text { approved by more than two-thirds of the } \\
\text { members of the collectives. It must be } \\
\text { approved by the township and provincial } \\
\text { government. }\end{array}$ & $\begin{array}{l}\text { (1) "Notice of General Office of the CPC } \\
\text { Central Committee, the general } \\
\text { office of the State Council on } \\
\text { further stabilize and improve the } \\
\text { rural land contract relationship" } \\
\text { ([1997] No. 16document) } \\
\text { (2) "Rural Land Contracting Law", } \\
\text { (RLCL, 2002) } \\
\text { (3) "Property Law" (2007) }\end{array}$ \\
\hline $\begin{array}{l}\text { III (2008- } \\
\text { present): } \\
\text { Emphasis on } \\
\text { the legal } \\
\text { protection of } \\
\text { land tenure. }\end{array}$ & $\begin{array}{l}\text { (1) Protect land tenure by enforcing the } \\
\text { use of land-use rights contracts. } \\
\text { (2) Existing land contracts must not be } \\
\text { changed for a long term. } \\
\text { (3) Promote land-use rights } \\
\text { registration/certificate as legal entitlement } \\
\text { for land-use rights. } \\
\text { (4) Illegal confiscation of contracted land } \\
\text { is banned. }\end{array}$ & $\begin{array}{l}\text { (1) "Decisions of the CPC Central } \\
\text { Committee on the several major } \\
\text { issues of rural reform and } \\
\text { development" (2008) } \\
\text { (2) "Opinions of the CPC Central } \\
\text { Committee and State Council in } \\
2009 \text { on promoting stable } \\
\text { development of agriculture and } \\
\text { continuous increase of farmers' } \\
\text { incomes" ([2009] No. 1 document) } \\
\text { (3) Opinions of the CPC Central } \\
\text { Committee and State Council in } \\
\text { 2009 on strengthening the balance } \\
\text { of urban and rural development and } \\
\text { further consolidating the basis of } \\
\text { agricultural and rural development" } \\
\text { ([2010] No. 1 document) }\end{array}$ \\
\hline
\end{tabular}

\footnotetext{
${ }^{8}$ A detailed account of these stages can be found in Section 3.
} 

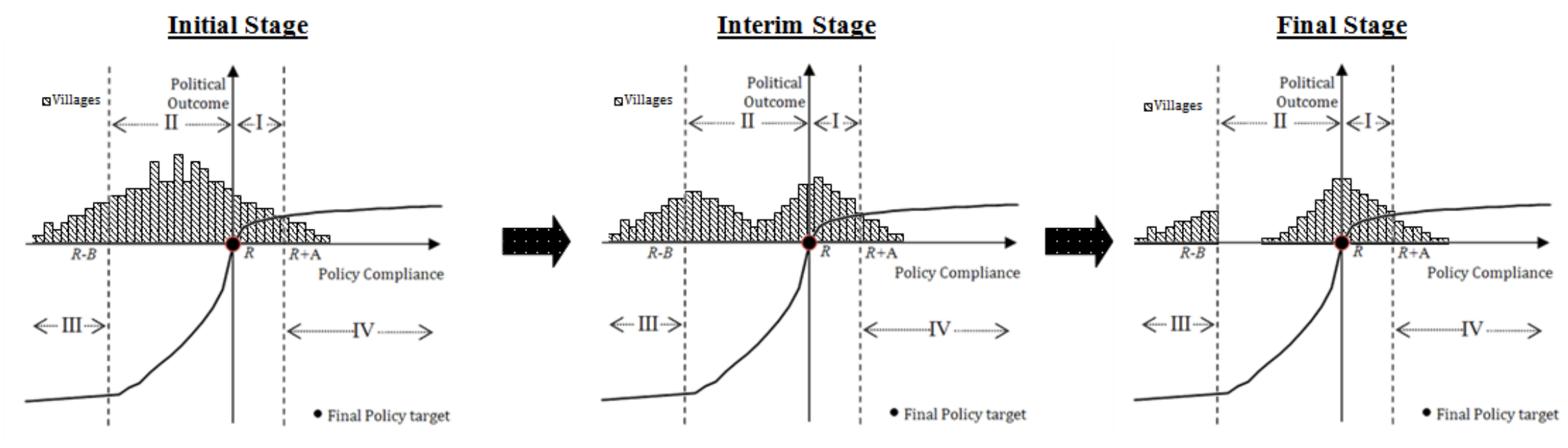

Figure 3a: Radical Reform under PT
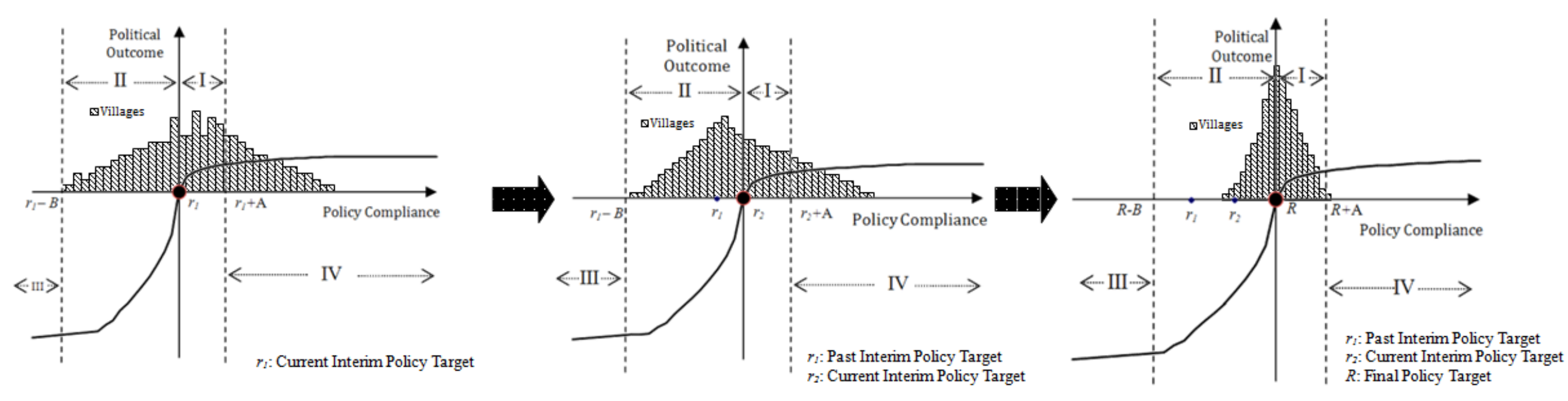

Figure 3b: Incremental Reform under PT 
To verify our theoretical framework, two hypotheses are tested based on Equation 3.

Hypothesis 1 (Induced Institutional Change Hypothesis): Land reallocation at the local level is determined by the social, economic, and geographic characteristics of the locality.

Specifically, we will test if $\alpha_{j}=0$ for $j=1,2, \ldots, k$. If the null hypothesis is rejected, then land reallocation activities are influenced by local endowment. Induced institutional change is a driving force for land reallocation reform.

Hypothesis 2 (Imposed Institutional Change Hypothesis): Land reallocation is subject to central government intervention.

For this hypothesis to be true, we need to test if $\beta=0$. If the null hypothesis is rejected, then the scale and frequency of land reallocation are affected by the intervention of the central government.

If both Hypothesis 1 and Hypothesis 2 are true with the endogeneity specified in equation $3 \mathrm{~b}$ taken into account, our theoretical framework as depicted in Figure 1 is verified. Understanding the history and current situation of rural land reallocation reform in China is important to verify these hypotheses. Thus, institutional background information is presented in the next section. Official statistics are limited and often at aggregated levels, so we utilize a unique set of survey data to provide a comprehensive overview of land reallocation in rural China.

\section{Rural Land Reallocation in China: Survey Data and Institutional Background}

In 1999, Renmin University of China (RUC) and the Rural Development Institute (RDI) in the US conducted a rural land survey in 17 Chinese provinces. Figure 4 shows the distribution of these provinces. The survey was repeated in 2001, 2005, 2008, and 2010 . It used a combination of multi-stage random sampling and convenience sampling ${ }^{10}$. The survey was conducted through home visits, which allowed villagers to be interviewed without being noticed or the presence of village leaders. A total of 8,589 complete questionnaires were collected in five surveys, averaging about 500 complete questionnaires for each of the 17 provinces. Over $90 \%$ of the questionnaires were from rural areas, and $71.2 \%$ of the sample came from within 10 kilometers of the nearest town or county. The average household size was 4.5 persons, with a per capita agricultural land area of $1.4 \mathrm{Mu}$ (one acre $\approx 6.07 \mathrm{Mu}$ ). On average, each household had 4.4 contracted land parcels. Respondents completed 7.4 years of education and were 46.2 years old on average. In 2010, about half of the surveyed households obtained $80 \%$ or more of their income from non-agricultural activities.

The 17 provinces covered in the survey homed $77 \%$ of the rural population in China ${ }^{11}$. Therefore, the survey data provided a comprehensive account of land reallocation practice in

\footnotetext{
9 The 2008 and 2010 surveys were conducted jointly by the Rural Development Institute, Renmin University of China, and Michigan State University.

10 The survey sampling consisted of two stages. In the first stage, 17 provinces were selected, including all major agricultural provinces. In the second stage, a minimum of 100 villages were chosen from each province; up to two households were interviewed for each selected village. To ensure sample representativeness, a maximum of six households were interviewed in each county and a maximum of three households were interviewed in each town.

${ }^{11}$ China Statistical Year Book, 2012 (http://www.stats.gov.cn/tjsj/ndsj/2012/indexeh.htm).
} 
the last decade. In this section, descriptive statistics of the survey are presented to provide an institutional background for the discussions to follow.

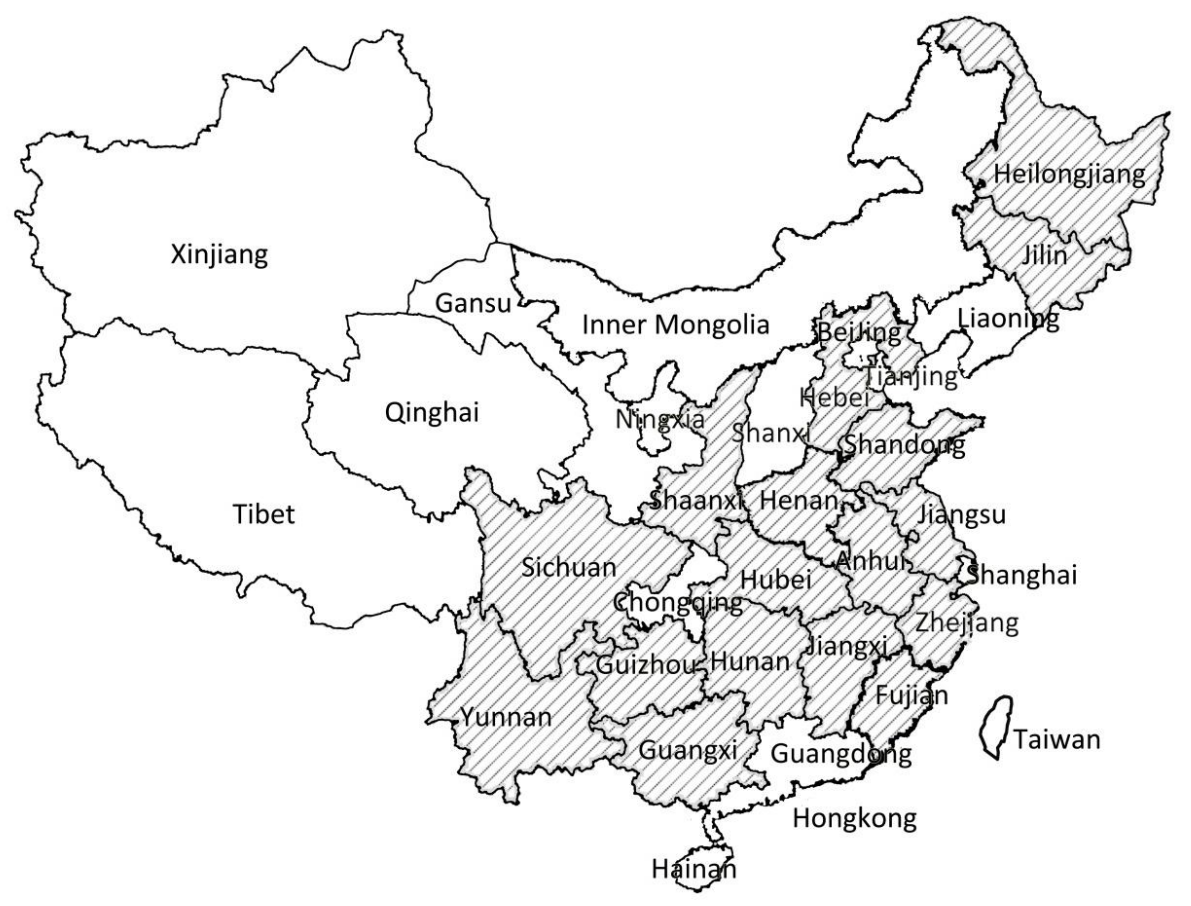

Figure 4: The 17 Surveyed Provinces

After the second round of land contracting in $1993^{12}$, land reallocation decreased in both quantity and frequency. First, the percentage of land reallocated since the first round of land contracting was $79.9 \%$ in 1999 and $82.6 \%$ in 2001, while the percentage of land reallocated since the second land contracting decreased to $37.5 \%$ in 2008 and $40.1 \%$ in 2010 (Table 2). Second, in the 1999 and 2001 surveys, approximately half of the villages did not have any land reallocation in the last two to three years. The 2010 survey revealed that about two-thirds of the villages did not have any land reallocation in the last two to three years, and about $50 \%$ of the villages did not have land reallocation in the last five years.

Table 2: Land reallocation frequency in the 1999 to 2010 survey

Villages that had land reallocation

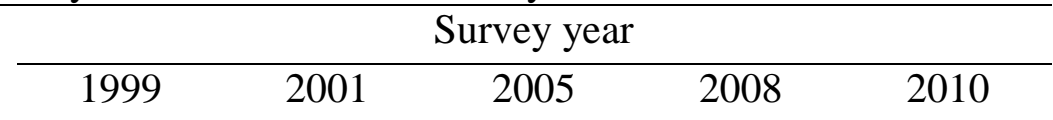

1984 - survey year

Frequency

Percentage

$79.9 \%$

$82.6 \%$

1993 - survey year

\footnotetext{
12 The launch of Document No. 1 in 1984 marked the beginning of the first round of land contracting. In this document, the central government stated that the land-use rights of farmers should be granted for a minimum of 15 years in their land contracts. In 1993, Document No. 11 was launched, in which the central government required land contracts to be extended 30 years upon expiry, which is referred to as the start of the second round of land contracting.
} 
Frequency

A large variation in land reallocation among provinces is also observed. In general, the scope of land reallocation is larger in plain areas than in hilly and mountainous areas. As shown in Figure 5, the percentage of villages with land reallocation was below $40 \%$ in Guizhou and Guangxi provinces, but well above 50\% in Jiangxi, Sichuan, and Henan province. On average, a higher ratio of villages in plain areas had land reallocation than those in mountainous and hilly areas (Table 3 ). This preliminary finding suggests that the geographic characteristics of villages may be important determinants of land reallocation decisions.

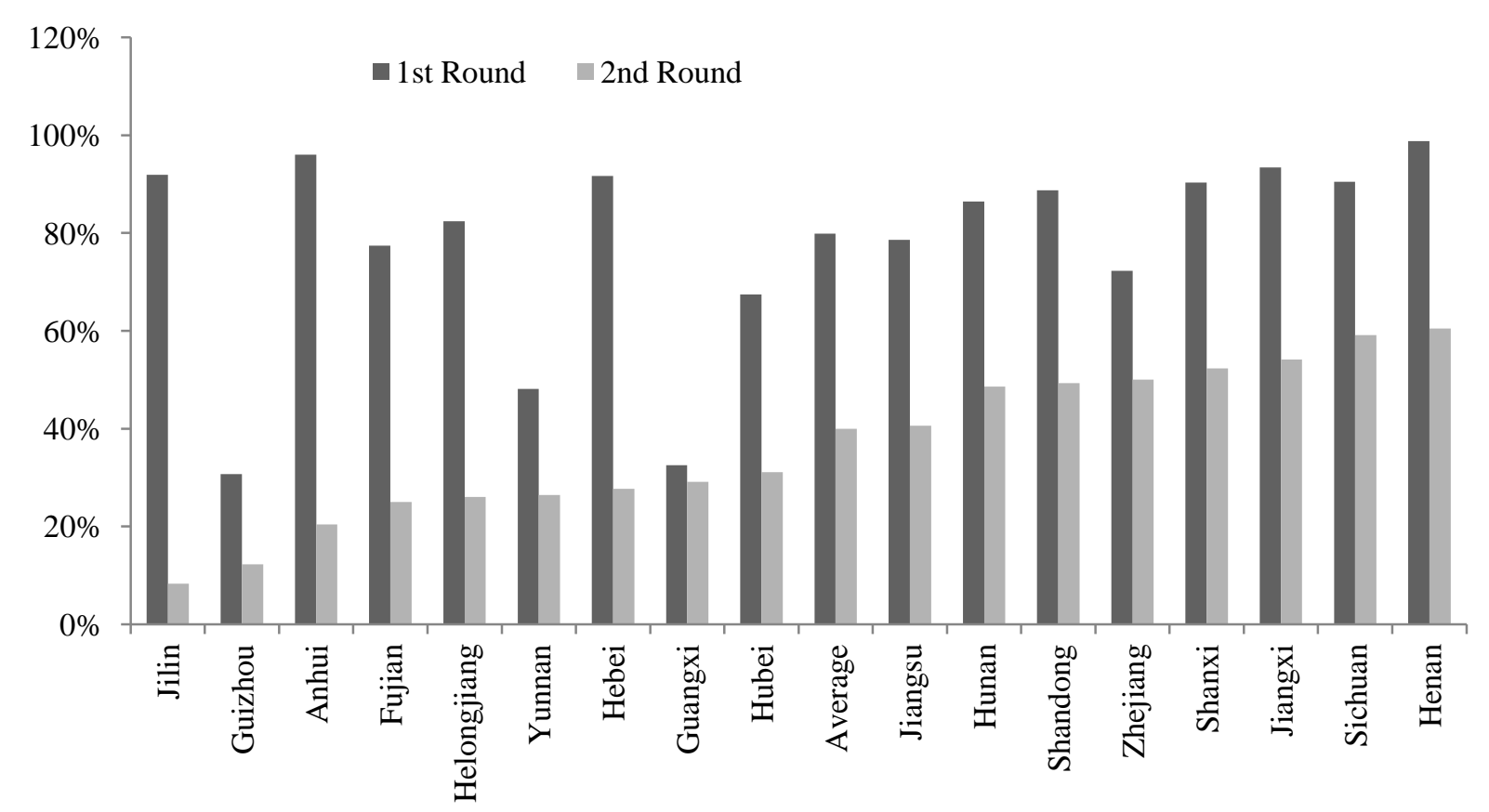

Figure 5: Percentage of villages that had land reallocation by province

Table 3: Percentage of villages that had land reallocation by geographic characteristics (\%)

\begin{tabular}{cccc}
\hline Survey Year & Mountainous areas & Hilly areas & Plain areas \\
\hline 2005 & 26.8 & 33.6 & 45.3 \\
2008 & 27.1 & 38.2 & 41.7 \\
2010 & 33.9 & 42.4 & 43.5 \\
\hline Average & 29.3 & 38.1 & 43.5 \\
\hline
\end{tabular}

Respondents were asked for the reasons of land reallocation in their villages and their attitudes toward the "No Reallocation" policy. First, we found that household demographic change is the main reason for land reallocation. Land expropriation and consolidation are also important factors causing land tenure adjustment (Table 4). Second, the majority of surveyed villagers $(42.5 \%)$ were in favor of the "No Reallocation" policy, with significant variations among provinces. The percentage of respondents who supported the policy in Jilin province (64.3\%) almost doubled that in Jiangsu province (35.6\%). Details of the survey statistics can be found in Table 5 . 
Table 4: Reasons for land reallocation by survey year (\%)

\begin{tabular}{lccccc}
\hline \multirow{2}{*}{ Reason } & \multicolumn{5}{c}{ Survey year } \\
\cline { 2 - 6 } & 2001 & 2005 & 2008 & 2010 & Average \\
\hline Demographic change & 78.8 & 73 & 64.5 & 66.1 & 69.6 \\
Land expropriation & 10.8 & 13.9 & 10.6 & 13.1 & 12.2 \\
Land consolidation & 0.7 & 5.2 & 8.6 & 9 & 6.5 \\
Natural disasters & - & 1.4 & 1 & 2.6 & 1.4 \\
Commercial activities & 2.3 & 2.5 & 5.3 & 2.6 & 3.3 \\
Village leader changes & 4.7 & 0.9 & 2.5 & 2.4 & 2.3 \\
Others & 2.7 & 3.1 & 7.6 & 4.2 & 4.7 \\
Total & 100 & 100 & 100 & 100 & 100 \\
\hline
\end{tabular}

Table 5: Villagers' attitude toward the "No Reallocation" policy by survey year

\begin{tabular}{cccccc}
\hline Attitude & \multicolumn{5}{c}{ Survey Year } \\
\cline { 2 - 6 } & 2001 & 2005 & 2008 & 2010 & Average \\
\hline Support & 42 & 43.8 & 45.3 & 38.2 & 42.5 \\
Neutral & 15.9 & 32.5 & 33.3 & 33.2 & 29.3 \\
Against & 42 & 23.7 & 21.4 & 28.6 & 28.2 \\
Total & 100 & 100 & 100 & 100 & 100 \\
\hline
\end{tabular}

As summarized in Table 1, rural land reallocation reform in China has undergone through three stages since 1984. The first stage was from 1984 to 1996, when both full reallocation and partial reallocation were allowed. In a series of central government documents and instructions regarding rural land contracting, "allowed" was used with regard to the regulation of land reallocation. Regardless of the conditions laid out for land reallocation, in principle, land redistribution is allowed within the 15 or 30 years of the contract term. Full reallocation is also permitted, although under tight control.

Stepping into the second stage (1997 to 2007), only partial reallocations were allowed before the land contract expires. In 1997, the central government issued the No. 16 document, in which the wording of the policy changed notably. Full reallocations were explicitly banned. However, small-scale adjustments among a few households (i.e., partial reallocation) were still allowed. This document and the 1998 Land Management Law laid out conditions of "partial reallocation." Partial reallocation must be approved by two-thirds of the members in a village representative assembly or two-thirds of the village representatives, as well as by the agricultural department in higher-level (town or county level) governments. Both Article 27 in the Rural Land Contract Law (2002) and Article 130 in the Property Law (2007) stipulate that during a contracting period, contractors are not allowed to reallocate contracted land. Under these regulations, partial reallocations are only allowed in "special cases in which contracted land is destroyed by natural disasters."

Stage three started in 2008 after a legislation was passed in the third meeting of the $17^{\text {th }}$ session of the Chinese Communist Party Central Committee. The legislation stipulated that "the current land contracting relationship must remain unchanged for a long term." Therefore, the emphasis of land reallocation practice is contracting relationship stability and legalization of land tenure. In two important documents issued in 2009 and 2012, regulations were set out for the registration and certification of collective land tenure. Village farmers must be given the "full package" of their contracted land, namely, the land, the official measurement of the 
land parcel size, the contract, and the land tenure registration document. Since then, China entered the stage of formal legalization of land tenure and implemented the land contracting relationship.

Our survey data reveal the significant impact of the central government's policies on land reallocation behaviors by local governments in China. The tighter control over major reallocation after the second round of land contracting is the main cause behind the notable drop in the size and frequency of land reallocation, as indicated in Table 2. Our survey data show that the percentage of villages that had land reallocation dropped from nearly $80 \%$ to about $40 \%$ after the second round of land contracting. In addition, the frequency of land reallocation decreased significantly in all provinces (Figure 5). Note as well that land reallocation practice varies with geographic characteristics (Table 3), and villages reallocate lands for a wide range of reasons (Table 4). As land reallocation generally poses a threat to tenure security, the majority of the respondents were either in support of or neutral to the 'No Reallocation' policy (Table 5). In this sense, land reallocation reform has been successful in terms of gaining local support.

The anecdotal evidence provides informal support to the hypotheses formulated in Section 2. Although the central government set the final policy target of "No Reallocation" as early as 1984, the level of policy compliance varied greatly over time and across the country. Nevertheless, the overall trend is movement toward the final policy target, as evidenced by the steadily decreasing frequency and scale of land reallocation in the second and third stages. The central government adjusted the policy targets in each stage based on the natural endowment and current level of policy compliance of the locality. The central government's flexible interpretation and enforcement of land reallocation policies also helped local governments to adjust their policy compliance level incrementally. Induced and imposed institutional changes are integrated seamlessly in this process. The formal test for the hypotheses using econometric methods and survey data are presented in the next section.

\section{Empirical Implementation}

The data used in this section were retrieved from two databases. Village- and household-level data were from the "RUC/RDI China 17 Provinces Village Survey Database," which was based on the survey conducted by RUC and RDI in the US. Per capita GDP and the contribution of non-agricultural sectors to national GDP (in percentage) were also included to capture the impact of regional economic development and changes in industry structure. These data were from the China Statistical Yearbook for Regional Economy (2006, 2009 \& 2010). Variable names, definitions, and descriptive statistics are given in Table 6.

As the respondents interviewed in each survey were different, the data in this study was not considered panel data. Moreover, the survey questionnaire design from 2005 onwards was different from that of previous years. Several of the variables used in our econometric models were missing from the 1999 and 2001 surveys. Therefore, we used the 2005, 2008, and 2010 survey data in this section only. After removing questionnaires with missing values, a total of 3,369 observations were included in the analysis ${ }^{13}$.

\footnotetext{
${ }^{13}$ In the questionnaire, when villagers were asked if their village practice land reallocation, about $5 \%$ of the respondents answered "not sure." These questionnaires were treated as incomplete and omitted from the analysis.
} 


\section{1: Measurement of land reallocation activities $\left(X_{i, t}\right)$}

Land reallocation activities are measured in two ways: the villages' decision to reallocate land (denoted as $\mathrm{X}_{1}$ in Table 6) and the frequency of land reallocation (denoted as $\mathrm{X}_{2}$ in Table 6). These are the two dependent variables in the present study. Following Brandt et al. (2004) and Deininger and Jin (2009), a Probit model was used to model the decision to reallocate land. Variable $\mathrm{X}_{2}$, the frequency of land reallocation, was truncated in the left tail at zero. A Tobit model was estimated by following the practices in the literature (see e.g., Brandt et al., 2004; Deininger \& Jin, 2009; Kung \& Bai, 2011).

\section{2: Measurement of local characteristics $\left(L_{i, j, t}\right)$}

We classified independent variables in our database into the following categories: geographic characteristics (Hill and Mountain), village characteristics (Expropriation and Distance), and economic development and industry structure (Nonagr and GDP). Time and province dummy variables were also included as controls.

\section{3: Treatment of central government policy target $\left(r_{t}\right)$}

The treatment of central government policy target was the most challenging task in the empirical implementation of our theoretical framework. First of all, this factor is difficult to observe or measure directly. Although the target of the central government is set on a specific date, when and for how long it takes effect is what we need for our model. However, an accurate measurement is difficult to come by. Second, not all of the determinants of $r_{t}$ (i.e., $Z_{i, l, t}$ in equation $3 \mathrm{~b}$ ) are observable. These determinants involve not only local characteristics, but also national factors such as national economy growth target, and social stability considerations to name a few. Consequently, a direct estimation of Equation $3 \mathrm{~b}$ will be prone to omitted variable biases and measurement error biases. In light of these data availability constraints, we estimated Equation (3) in its reduced form as follows:

$X_{i, t}=\alpha_{0}+\sum_{j=1}^{k} \alpha_{j} L_{i, j, t}+\beta r_{t}^{*}+\varepsilon_{i, t}$

where $r_{t}^{*}$ is a proxy of $r_{t}$, which is inherently endogenous and has measurement errors. Specifically, we use two land titling variables as the proxies of $r_{t}$. The first one is whether a village issues land rights certificates ${ }^{14}$ to its villagers (denoted as Certificate in Table 6). The second variable is whether "reallocation is prohibited before expiry date" is specifically included as an article in land rights certificates (denoted as Article in Table 6). These variables can be seen as two interim land reallocation policy targets at different stages, with Certificate preceding Article. This finding not only facilitates the test for Hypothesis 2, but also the verification of the incremental reform proposition derived from our theoretical framework.

Technically, the inclusion of "reallocation is prohibited before expiry date" as an article in land rights certificates seems to be redundant. If a land parcel is leased for 30 years and the lessee receives a land rights certificate, then land-use rights should be protected during the entirety of the lease term. However, in China, anything not specifically banned is considered to be acceptable. If "reallocation is prohibited before expiry date" is not included in land

\footnotetext{
${ }^{14}$ This is similar to the land title deed in a freehold land rights system, except that the rights protected by the deed are land-use rights only.
} 
rights certificates, the understanding is that reallocation may be permissible. The central government's flexible interpretation of the "No Reallocation" policy at different stages also means that contracted land parcels can be taken back if certain conditions are met (see Table 1 for details). There are gray areas where basic land rights certificates will not offer enough land-use rights protection. If such an article is included in land rights certificates, it will effectively remove the land parcels concerned from these gray areas. In other words, the issuing of land rights certificates offers basic land tenure protection while the "reallocation is prohibited before expiry date" article is an extra layer of protection. Certificate captures the importance of "formality" of land rights certificates, and Article measures the impact of the "functionality" of these certificates.

The central government required land right certificates to be issued to all rural land contractors as early as in 1997 and urged the implementation of this policy by issuing two important documents in 2009 and 2010. However, the central government's enforcement to include the "reallocation is prohibited before expiry date" article in land rights certificates has not been as strong and specific. Therefore, the issuing of land rights certificates is an interim policy target to be achieved before the standardization of land rights certificates (e.g., the inclusion of the "reallocation is prohibited before expiry date" article).

As both interim policy targets are still in effect, the impact of Certificate is expected to be more significant than that of Article. In our 2008 survey, around 50\% of the contractors were issued land rights certificates, among which only $15 \%$ had the "reallocation is prohibited before expiry date" article included. This is consistent with our expectation on the coefficient estimates of these two policy target variables.

\section{4: Econometric methods}

Certificate and Article are indicators of two important interim targets set by the central government to achieve its final land reallocation policy target, that is, "No Reallocation." These two variables capture the effect of central government policies, but are also affected by local policy compliance level, which are also included in model (4) as the dependent variable. Hence, the inclusion of Certificate and Article in Equation (4) introduces endogeneity to the model estimation process. In Saint-Macary et al.'s (2009) analysis of rural investment in Vietnam, they argued that land right certificates were often issued to all villagers at the same time, which effectively removed its endogeneity, if any. This is not the case in our analysis, where land rights certificates were distributed throughout a sampling period of over two decades (i.e., from 1984 to 2010) and across a much larger, more diversified geographic region. These temporal and geographic variations were not fully captured by $L_{i, j, t}$ in model (4). If these effects are not accounted for, model estimation will suffer from endogeneity biases. We therefore re-estimated model (4) using the Probit-IV and Tobit-IV approaches (Woodridge, 2010).

Two instrumental variables were used in our IV models ${ }^{15}$ : the percentage of land right certificates issued in the county where a village belongs (denoted as Certificate\% in Table 6) and the percentage of land rights certificate with clauses that prohibit land reallocation in the county where a village belongs (denoted as Article\% in Table 6). For each village, these variables are calculated using data from all other villages within the same county. Since the

\footnotetext{
15 The choice of instrumental variables is largely based on the approach used in Kung and Bai (2011).
} 
calculations of Certificate $\%_{i, t}$ and Article $\%_{i, t}$ do not include data from village $i$ in period $t$, these two instrumental variables are unlikely to be correlated with $\varepsilon_{i, t}$. On the other hand, villages within the same county often have commonality in land reallocation behaviors. The correlation between these instrumental variables and $r_{t}^{*}$ is likely to be high. Therefore, they satisfy the criteria of good instrumental variables.

The validity of instrumental variables was verified using the following procedures. First, Pearson correlation coefficients between Certificate and Article and their instrumental variables (i.e., Certificate\% and Article\%) were 0.56 and 0.52 respectively and were significant at the $1 \%$ level. Second, the standard Probit and Tobit models were re-estimated by including the two instrumental variables, and the coefficient estimates for Certificate\% and Article\% were statistically insignificant at the 5\% level. The instrumental variables passed the exogeneity test and over-identification test ${ }^{16}$.

Table 6: Variable definition and descriptive statistics

\begin{tabular}{|c|c|c|c|c|}
\hline Category & Variable Name & Variable Definition & Mean & $\begin{array}{l}\text { Standard } \\
\text { Deviation }\end{array}$ \\
\hline \multirow[t]{2}{*}{$\begin{array}{l}\text { Dependent } \\
\text { variable }\end{array}$} & $X_{1}$ & $\begin{array}{l}=1 \text { if there are land reallocations since the } \\
\text { second round of land contracting, and } 0 \\
\text { otherwise }\end{array}$ & 0.3 & 0.46 \\
\hline & $X_{2}$ & Number of land reallocations & 0.71 & 1.56 \\
\hline \multirow[t]{2}{*}{$\begin{array}{l}\text { Geographic } \\
\text { characteristics }\end{array}$} & Hill & $\begin{array}{l}=1 \text { if the village is located in a hilly area, and } \\
0 \text { otherwise }\end{array}$ & 0.28 & 0.45 \\
\hline & Mountain & $\begin{array}{l}=1 \text { if the village is located in a mountainous } \\
\text { area, and } 0 \text { otherwise }\end{array}$ & 0.37 & 0.48 \\
\hline \multirow[t]{2}{*}{$\begin{array}{l}\text { Village } \\
\text { characteristics }\end{array}$} & Expropriation & $\begin{array}{l}=1 \text { if there are land expropriation since the } \\
\text { second round of land contracting, and } 0 \\
\text { otherwise }\end{array}$ & 0.33 & 0.47 \\
\hline & Distance & Distance to the nearest county $(\mathrm{km})$ & 9.56 & 8.91 \\
\hline \multirow{2}{*}{$\begin{array}{l}\text { Economic } \\
\text { development } \\
\text { and industry } \\
\text { structure }\end{array}$} & Nonagr & $\begin{array}{l}\text { Contribution of non-agricultural sectors to } \\
\text { national GDP (\%, county level) }\end{array}$ & 0.74 & 0.12 \\
\hline & $G D P$ & $\begin{array}{l}\text { Per capita GDP (in ten thousands RMB , } \\
\text { county level) }\end{array}$ & 1.59 & 1.76 \\
\hline \multirow[t]{2}{*}{ Land titling } & Certificate & $\begin{array}{l}=1 \text { if land rights certificates were issued in } \\
\text { the village, and } 0 \text { otherwise }\end{array}$ & 0.58 & 0.49 \\
\hline & Article & $\begin{array}{l}=1 \text { if no land reallocation is specified in land } \\
\text { rights certificates, and } 0 \text { otherwise }\end{array}$ & 0.07 & 0.26 \\
\hline \multirow[t]{2}{*}{ Year dummy } & $Y 2008$ & $=1$ in year 2008 , and 0 otherwise & & \\
\hline & $Y 2010$ & $=1$ in year 2010 , and 0 otherwise & & \\
\hline \multirow{3}{*}{$\begin{array}{l}\text { Province } \\
\text { dummy }\end{array}$} & Hunan & $=1$ if Hunan province, and 0 otherwise & & \\
\hline & $\ldots$ & $\ldots$ & & \\
\hline & Anhui & $=1$ if Anhui province, and 0 otherwise & & \\
\hline \multirow[t]{2}{*}{$\begin{array}{l}\text { Instrument } \\
\text { variables }\end{array}$} & Certificate\% & $\begin{array}{l}\text { Percentage of land rights certificates issued } \\
\text { in the county where a village belongs }\end{array}$ & & \\
\hline & Article\% & $\begin{array}{l}\text { Percentage of land rights certificate with } \\
\text { clauses that prohibit land reallocation in the } \\
\text { county where a village belongs }\end{array}$ & & \\
\hline
\end{tabular}

\section{Empirical Findings and Discussions}

Table 7 presents the results from the standard Probit and Tobit models and their IV

\footnotetext{
${ }^{16}$ Kung and Bai (2011) also use this approach for the over-identification test in their IV models.
} 
counterparts for comparison. The sign and magnitude of the coefficient estimates for Certificate and Article changed notably in the IV models, whereas the coefficient estimates for other independent variables remained largely unchanged. The coefficient estimate of Certificate was significantly larger, and the coefficient estimate of Article became insignificant in the IV models. The evidence, coupled with the validity test results of the IV variables, supports the use of the IV approach in our analysis. The discussions hereafter are based on the Probit-IV and Tobit-IV model results.

\section{The test for the induced institutional change hypothesis (Hypothesis 1)}

Both models support the induced institutional change hypothesis. Geographic characteristics have significant impact on land reallocation behavior. The coefficients of Hill and Mountain are negative and statistically significant. Villages with poor geographic conditions have higher transaction cost (including measurement cost and negotiation cost, among others) for land reallocations, which discourage land redistribution among villagers. This observation is consistent with the findings in the case study by Kung and Zhou (1999) and the studies on major land reallocation by Kung and Bai (2011). A similar conclusion can be reached based on the coefficient estimates of Distance. In villages that are further away from local economic centers (i.e., counties in our analysis) are less affected by the rapid urbanization process. Land prices will be lower, and so will the transaction cost of land reallocation. This condition will encourage land reallocation, all else being equal. The positive coefficient of Distance captures the relationship between land resource scarcity and land reallocation decision and frequency.

This hypothesis is further supported by the coefficient estimate of GDP, which is negative and significant at the $10 \%$ level in both models. Economic growth causes the value of land and labor to appreciate. Since land value often appreciates greater and faster than labor cost, the net effect is an increase in the relative price of $\operatorname{land}^{17}$, and consequently, the need for a reduction in land reallocation and well-defined property rights.

The coefficient of Nonagr is positive and significant at the 5\% level in all models. The effect of non-agricultural sectors is twofold. Although the development of non-agricultural sectors generally leads to land value appreciation, it also causes changes in rural demographics. These changes will normally induce land reallocation. The former effect is likely to be picked up by the variable GDP to a certain extent. After this effect is controlled for, Nonagr mostly captures the positive impact from non-agricultural sectors on land reallocation decision and

17 From 1999 to 2011, the disposable income of urban households increased from 5,854RMB to 21,810RMB per annum at an annual growth rate of $11.6 \%$. Similarly, the disposable income of rural households increased from 2,210RMB to 6,977RMB at an annual growth rate of $10 \%$. Meanwhile, land price increased from 57RMB per square meter to $471 \mathrm{RMB}$ per square meter at an annual growth rate of $19.3 \%$. The growth rate of land price was twice as large as those of the urban and rural dispensable income growth rates. All statistics are from China Land and Resources Statistical Yearbook, 2012 and China Land and Resources Year Book 2012. 
frequency ${ }^{18}$. Similarly, rural land expropriation changes farmland supply directly, and subsequently induces land reallocations. As a result the coefficient estimate for Expropriation is significant and positive. This is also consistent with our findings in Table 4 where land expropriation is identified as the second most important reason for land reallocations.

Although rural land reallocation reform is characterized by rapid and radical changes, our empirical evidence still supports the long-established "induced institutional hypothesis" (see e.g., Hayami \& Ruttan, 1971; Ruttan \& Hayami, 1984; North \& Thomas, 1973; North, 1981 $\& 1990)$. The scarcer the land resources, the higher the cost of land reallocation. Consequently, land reallocation is less likely to happen. The long-term effect of these natural endowment constraints in rural China will be reduced land reallocation frequency, extended land contract term, and improved tenure security.

${ }^{18}$ The VIFs of GDP and Nonagr are 1.3 and 1.4 respectively. The two variables are correlated, but do not suffer from serious multicollinearity problems. Therefore, the net effect of the two variables can be estimated accurately. 
Table 7: Model Estimations

\begin{tabular}{|c|c|c|c|c|c|}
\hline \multicolumn{2}{|c|}{ Independent Variables } & \multicolumn{4}{|c|}{ Dependent Variables } \\
\hline \multirow[b]{2}{*}{ Category } & \multirow{2}{*}{$\begin{array}{c}\text { Variable } \\
\text { name }\end{array}$} & \multicolumn{2}{|c|}{$\begin{array}{l}\text { Decision of land reallocation } \\
\qquad\left(\mathrm{X}_{1}\right)\end{array}$} & \multicolumn{2}{|c|}{$\begin{array}{l}\text { Frequency of land reallocation } \\
\qquad\left(\mathbf{X}_{2}\right)\end{array}$} \\
\hline & & Probit & Probit-IV & Tobit & Tobit-IV \\
\hline \multirow{2}{*}{$\begin{array}{l}\text { Resource } \\
\text { endowment }\end{array}$} & Hill & $-0.1230 *$ & $-0.1196 *$ & $-0.6494 * * *$ & $-0.6376 * * *$ \\
\hline & Mountain & $-0.2127 * * *$ & $-0.2030 * * *$ & $-0.6231 * * *$ & $-0.5969 * * *$ \\
\hline \multirow{2}{*}{$\begin{array}{l}\text { Village } \\
\text { characteristics }\end{array}$} & Expropriation & $0.4327 * * *$ & $0.4356 * * *$ & $1.3954 * * *$ & $1.4046 * * *$ \\
\hline & Distance & $0.0098 * * *$ & $0.0100 * * *$ & $0.0309 * * *$ & $0.0317 * * *$ \\
\hline \multirow{2}{*}{$\begin{array}{l}\text { Economic } \\
\text { development } \\
\text { and industry } \\
\text { structure }\end{array}$} & Nonagr & $0.7208 * *$ & $0.7243 * *$ & $2.2369 * *$ & $2.2301 * *$ \\
\hline & $G D P$ & $0.0316 *$ & $0.0313 *$ & $0.1180 * *$ & $0.1180 * *$ \\
\hline \multirow[t]{2}{*}{ Land titling } & Certificate & $-0.1393 * * *$ & $-0.1996 *$ & $-0.4955 * * *$ & $-0.6606 *$ \\
\hline & Article & $-0.1723 *$ & -0.1483 & $-0.6005 *$ & -0.6630 \\
\hline \multirow[t]{2}{*}{ Year dummy } & Y2008 & -0.0414 & -0.0445 & 0.0912 & 0.0873 \\
\hline & $Y 2010$ & $-0.1044 *$ & -0.0898 & 0.1573 & 0.1845 \\
\hline \multirow{16}{*}{$\begin{array}{l}\text { Province } \\
\text { dummy }\end{array}$} & Hunan & $-0.2745 * *$ & $-0.2729 * *$ & $-0.7427 *$ & $-0.7435 *$ \\
\hline & Hubei & $-0.5584 * * *$ & $-0.5623 * * *$ & $-1.6659 * * *$ & $-1.6833 * * *$ \\
\hline & Zhejiang & $-0.3398 * *$ & $-0.3438 * *$ & $-0.8678 * *$ & $-0.8620 * *$ \\
\hline & Jiangsu & $-0.3038 * *$ & $-0.2945 * *$ & $-0.8904 * *$ & $-0.8720 * *$ \\
\hline & Jiangxi & $-0.2354 *$ & $-0.2298 *$ & -0.5478 & -0.5276 \\
\hline & Fujian & $-0.7998 * * *$ & $-0.8060 * * *$ & $-2.5862 * * *$ & $-2.6180 * * *$ \\
\hline & Jilin & $-1.2897 * * *$ & $-1.2850 * * *$ & $-4.0365 * * *$ & $-4.0427 * * *$ \\
\hline & Heilongjiang & $-0.7568 * * *$ & $-0.7634 * * *$ & $-2.0711 * * *$ & $-2.1056 * * *$ \\
\hline & Sichuan & -0.1973 & -0.1895 & -0.2941 & -0.2714 \\
\hline & Guangxi & $-1.1515 * * *$ & $-1.1452 * * *$ & $-3.6096 * * *$ & $-3.6042 * * *$ \\
\hline & Guizhou & $-1.7685 * * *$ & $-1.7728 * * *$ & $-5.4870 * * *$ & $-5.4965 * * *$ \\
\hline & Yunnan & $-0.9171 * * *$ & $-0.9140 * * *$ & $-2.9720 * * *$ & $-2.9630 * * *$ \\
\hline & Shanxi & $-0.3166 * *$ & $-0.3339 * *$ & $-1.2471 * * *$ & $-1.2958 * * *$ \\
\hline & Hebei & $-0.5819 * * *$ & $-0.5945 * * *$ & $-2.0956 * * *$ & $-2.1413 * * *$ \\
\hline & Henan & $-0.4784 * * *$ & $-0.4839 * * *$ & -0.6063 & -0.6246 \\
\hline & Anhui & $-1.3026 * * *$ & $-1.2937 * * *$ & $-4.2346 * * *$ & $-4.2269 * * *$ \\
\hline \multicolumn{2}{|l|}{ Sample size } & 3369 & 3360 & 3369 & 3360 \\
\hline \multirow{2}{*}{\multicolumn{2}{|c|}{$\begin{array}{l}\mathrm{LR} \mathrm{Chi}^{2} \text { / } \\
\text { Wald Chi }\end{array}$}} & 501.90 & 415.78 & 526.52 & 408.27 \\
\hline & & $(\mathrm{p}<0.01))$ & $(\mathrm{p}<0.01))$ & $(\mathrm{p}<0.01))$ & $(\mathrm{p}<0.01))$ \\
\hline \multicolumn{2}{|l|}{ Pseudo $\mathbf{R}^{2}$} & 0.1223 & - & 0.0672 & - \\
\hline
\end{tabular}

Note: Intercept terms were included in all models but not reported in the table. ${ }^{*}, * *$, and $* * *$ represent the $10 \%, 5 \%$, and $1 \%$ significance levels, respectively.

The test for the imposed institutional changes hypothesis (Hypothesis 2)

The coefficient estimate of Certificate is significant and negative. In comparison, the standard 
of land rights certificates is less important than the certificates themselves. The variable Article is not statistically significant in both IV models. This result is also robust in several alternative model specifications we used before arriving at the final models given in Table $7^{19}$. The issuing of land rights certificates provides rural land contractors with basic land tenure protection. At the same time, it still leaves local governments the flexibility to reallocate land parcels when necessary. Local governments are willing to comply even when faced with the possibility of reallocating the contracted land parcels in the near future. On the other hand, the inclusion of the "reallocation is prohibited before expiry date" article in land rights certificates removes the possibility of reallocating the contracted land parcels. Naturally, only villages without much need for land reallocation will risk including this article in their land rights certificates. As a result, the overall level of compliance is low for this policy target, and there are limited variations in the frequency and scale of land reallocation practice among villages that complied ${ }^{20}$. The combined effect is the insignificant effect of this policy target on land reallocation practice in rural China.

Two important conclusions can be drawn from these observations. First of all, the findings support the imposed institutional changes hypothesis (i.e., Hypothesis 2), where government intervention serves as a formal constraint on land reallocation behaviors. In villages where the central government's "No Reallocation" policies are effectively implemented through the issuing of land rights certificates, land reallocation is less likely to happen and with low frequency. This is the net effect of central government policies after local endowment factors and temporal and regional variations have been controlled for. A combined force of induced and imposed institutional changes has been driving the land reallocation reform in rural China.

Second, the different effect from Certificate and Article offers empirical support to the incremental nature of land reallocation reform as described in Equations 3(a) and 3(b). The central government did not adopt a radical approach to achieve its final "No Reallocation" target. Instead, achievable interim policy targets were set and local governments were allowed to interpret related government documents flexibly and reach interim targets incrementally. In this empirical analysis, Certificate is an example of an early stage interim target (such as target $r_{1}$ in Figure 3b), with Article being the interim target in the next stage (such as target $r_{2}$ in Figure 3b). Our estimation period can be best represented by the middle panel in Figure 3b, where more villages are concentrated around $r_{1}$, but fewer ones are close to $r_{2}$. Therefore, the effect of $r_{2}$ is less significant at this stage. Knowing that $r_{1}$ is achievable for most local governments and has been successfully achieved by a number of localities at this stage, the central government demands a higher level of compliance by issuing several important documents. On the other hand, the enforcement of $r_{2}$ is still slow and flexible, with the

\footnotetext{
${ }^{19}$ In these alternative models, we used 1) variables such as the level of standardization of land rights certificates, 2) alternative tests for the exogeneity of instrumental variables, or 3) different subsamples. Results are not presented here, but are available from the authors upon request.

${ }^{20}$ For villages that have the "reallocation is prohibited before expiry date" article in land rights certificates, the average frequency of land reallocation (i.e., sample mean of $X_{2}$ ) is 0.4 with a standard deviation of 0.9 . For villages that issued land certificates without this article, the average frequency of land reallocation is 0.7 with a standard deviation of 1.6.
} 
understanding that once most local governments have reached $r_{1}$ the compliance to $r_{2}$ can speed up. This finding offers support to link 4(b) in Figure 1, and consequently completes the empirical verification of the theoretical model proposed in Section 2. It is also in line with North's (1990) argument that most institutional changes are incremental.

\section{Conclusions}

The "induced versus imposed" institutional change debate has yet to reach a consensus in the studies of rural land reallocation reform in China. Contrary to the common treatment of the two types of institutional changes as competing theories, we unify them in one theoretical framework under PT. After more than 30 years of decentralization reform, the political structure in China can be described as "federalism with political centralization" (Blanchard \& Shleifer, 2001; Montinola et al., 1995). The central government remains its absolute power in the appointment and promotion of local government officials. Hence, compliance to central government policies is of top priority for local governments. Meanwhile, a "central-local co-agency" system is in effect, in which the central government gives consideration to the needs and feedback of local governments ( $\mathrm{Li}, 2010)$. This central-local government dynamic finds its place in all aspects of China's political and economic development. The land reallocation reform of China is no exception. In this sense, the relationship between induced and imposed institutional changes should be complementary instead of contradictory in China's rural land reallocation reform. Our PT-based theoretical model provides a framework to describe and understand such a relationship. The interim policy targets set by the central government serve as the reference points for local governments. Whether and to what extent a local government will comply with a certain policy target depends on its current policy compliance level relative to the reference point. The key is to set the reference point such that all local governments are in the effective zones and are motivated to comply. This goal can only be achieved by taking into account local natural endowment and policy compliance level while setting central government policy targets. Through this central-local government interaction, induced and imposed institutional changes are integrated.

Our theoretical model is verified using survey data from 17 Chinese provinces between 2005 and 2010. We find evidence to support both induced and imposed institutional change hypotheses. The decision and frequency of land reallocation are affected by both local natural endowment and central government policy. Our findings also suggest that land reallocation reform in China is incremental, with interim policy targets from different stages taking effect gradually. The theoretical model and empirical findings provide an explanation to the "persistence of seemingly inefficient institutions" puzzle (Kung \& Bai, 2011). The incremental implementation of the "No Reallocation" policy is the reason behind the widespread, diversified land reallocation practices across the country. In other words, it is not that the central government policies are not in effect or the local government ignored central government policies. On the contrary, the flexibility in regulations at different stages gives the local government sufficient space to adjust local policies. This space enables them to interpret and comply with central government polices based on local nature resource endowment and economy development state. This process moves all localities slowly yet steadily toward the 
final "No Reallocation" target. The incremental implementation of the "No Reallocation" policy is the reason behind the widespread, diversified land reallocation practices across the country; this policy also contributes to the success of rural land-use rights reform in China. The theoretical model can be used to study a wide range of government-led institutional changes in China, such as affordable housing schemes and the National New-type Urbanization Plan (2014-2020) ${ }^{21}$.

Although survey findings offer sufficient support to our theoretical framework, our econometric implementation can be improved by using a panel data set. The use of the instrumental variable approach helps to alleviate endogeneity problems, but the level of improvement depends heavily on the quality of the instrumental variables. When the data are collected from a large geographically and economically diversified region across five years, measurement errors and omitted variable biases also affect the reliability and validity of the findings. In this case, a panel data set will be helpful. However, the fast urbanization process in China makes this a challenging undertaking. The rural population has been changing in such a fast pace that following the same households in each survey is not feasible. Such data will be available when China's urbanization process reaches a certain level such that migration from rural to urban areas is stabilized. Studies using panel data, once they are available, can augment our understanding of the rural land reallocation reform in China.

Transaction cost theory is the backbone of new institutional economics (Eggerstsson, 2013). However, the static, ahistorical and universalistic nature of the theory limits its ability to explain the formation and development of institutions and organizations (Meramveliotakis and Milonakis, 2010). The solution is not to abandon transaction cost theory, but to seek improvement by developing a more dynamic theory (Hodgson, 2010; Meramveliotakis and Milonakis, 2010). Our PT-based model could be further developed as an attempt along this direction. For example, our model involves multiple stages and multiple targets. This framework not only incorporates the crucial time dimension that is missing from transaction cost theory, but also considers historical formation and development of institutions. The model also recognizes the feedback effect of local government's policy compliance on central government's policy making decisions, which is considered 'of the second order' and consequently untreated in transaction cost theory (Williamson, 2000). In the same vein of the recent development in evolutionary and institutional economics, our model emphasizes dynamics, uncertainty and bounded rationality (Hodgson, 2007, Hodgson \& Huang, 2012). It may also help to reconcile the ongoing debate regarding the role of states in the evolution of institutions (see, for example, Chang, 2010). These broader issues are beyond the scope of this study, but certainly warrant further investigation in future research.

\footnotetext{
21 The plan was issued by the Central Committee of the Communist Party of China and the State Council as the first official plan on urbanization (http://news.xinhuanet.com/english/indepth/2014-03/17/c_133192840.htm).
} 


\section{References}

1. Ash, R.F., 1988. The evolution of agricultural policy. China Quarterly 116, 529-555.

2. Barberis, N.C., 2013. Thirty years of prospect theory in economics: A review and assessment. Journal of Economic Perspectives 27 (1), 173-195.

3. Benjamin, D., Brandt, L., 2002. Property rights, labour markets, and efficiency in a transition economy: the case of rural China. Canadian Journal of Economics. 35 (4), 689-716.

4. Binswanger H., Deininger, K., and Feder, G., 1995. Chapter 42 Power, distortions, revolt and reform in agricultural land relations. In Behrman J. and Srinivasan T.N. (eds.) Handbook of Development Economics, Volume III, Elsevier Science B.V., 1995.

5. Blanchard, O., Shleifer, A., 2001. Federalism with and without political centralization: China versus Russia. IMF Staff Papers 48, 171-179.

6. Brandt L., Huang J., Li G., Rozelle S., 2002. Land rights in rural China: facts, fictions and issues. The China Journal 47, 67-97.

7. Brandt, L., Rozelle, S., Turner, M.A., 2004. Local government behavior and property right formation in rural China. Journal of Institutional and Theoretical Economics160 (4), 627-662.

8. Cai, F., Wang, M.Y., 2010. Growth and structural changes in employment in transition China. Journal of Comparative Economics 38 (1), 71-81.

9. Chang, H.J., 2011. Institutions and economic development: theory, policy and history. Journal of Institutional Economics 7, 473-498.

10. Davis, L.E., and North, D.C., 1971. Institutional change and American economic growth, Cambridge University Press.

11. De Soto, H., 2000. The mystery of capital: why capitalism triumphs in the West and fails everywhere else. Bantam, London.

12. Deininger, K., Jin, S.Q., 2003. The impact of property rights on households' investment, risk coping, and policy preferences: evidence from China. Economic Development and Cultural Change 51 (4), 851-882.

13. Deininger, K., Jin, S.Q., 2009. Securing property rights in transition: lessons from implementation of China's rural land contracting law. Journal of Economic Behavior \& Organization 70 (1-2), 22-38.

14. DellaVigna, S., 2009. Psychology and economics: evidence from the field. Journal of Economic Literature 47 (2), 315-372.

15. Diamond, N., 1985. Rural collectivization and decollectivization in china - A review article. Journal of Asian Studies 44 (4), 785-792.

16. Eggertsson, T., 2013. Quick guide to New Institutional Economics. Journal of Comparative Economics 41, 1-5.

17. Gaynor, M., Putterman, L., 1993. Productivity consequences of alternative land division methods in China decollectivization - an econometric-analysis. Journal of Development Economics 42 (2), 357-386.

18. Goldfarb, A., Ho, T.H., Amaldoss, W., Brown, A.L., Chen, Y., Cui, T.H., Galasso, A., Hossain, T., Hsu, M., Lim, N., Xiao, M., Yang, B.T., 2012. Behavioral models of managerial decision-making. Marketing Letters 23 (2), 405-421.

19. Hayami, Y, Ruttan, V.W., 1971. Agricultural development: an international perspective. Johns Hopkins Press, Baltimore.

20. Hodgson, G.M., 2007. Evolutionary and institutional economics as the new mainstream? Evolutionary and Institutional Economics Review 4, 7-25.

21. Hodgson, G.M., 2010. Limits of transaction cost analysis, in: Klein, P.G., Sykuta, M. (Eds.), The Elgar Companion to Transaction Cost Economics. Edward Elgar, Cheltenham 
UK and Northampton MA, pp. 297-306.

22. Hodgson, G.M., Huang, K.N., 2012. Evolutionary game theory and evolutionary economics: are they different species? Journal of Evolutionary Economics 22, 345-366.

23. Jacoby H.G., Li G., Rozelle S., 2002. Hazards of expropriation: tenure insecurity and investment in rural China. American Economic Review 92 (5), 1420-1447.

24. Jin, H., Qian, Y., Weingast, B.R., 2005. Regional decentralization and fiscal incentives: federalism, Chinese style. Journal of Public Economics 89 (9-10), 1719-1742.

25. Kahneman, D., Tversky, A., 1979. Prospect theory-analysis of decision under risk. Econometrica 47 (2), 263-291.

26. Kochin, M.S., 1996. Decollectivization of agriculture and the planned economy. American Journal of Political Science 40 (3), 717-739.

27. Kojima, R., 1988. Agricultural organization-new forms, new contradictions. China Quarterly 116, 706-735.

28. Kung, J.K.S., 1995. Equal entitlement versus tenure security under a regime of collective property-rights - Peasants preference for institutions in post-reform Chinese agriculture. Journal of Comparative Economics 21 (1), 82-111.

29. Kung, J.K.S., 2000. Common property rights and land reallocations in rural China: Evidence from a village survey. World Development 28 (4), 701-719.

30. Kung, J.K.S., Bai, Y., 2011. Induced institutional change or transaction costs? The economic logic of land reallocations in Chinese agriculture. Journal of Development Studies 47 (10), 1510-1528.

31. Kung, J.K.S., Zhou, F., 1999. Case studies of China' rural land reallocation, in China Economics 1999, page 286-307, edited by Y. F. Lin, Shanghai People's Publishing, Shanghai, China.

32. Li, G., Rozelle, S., Brandt, L., 1998. Tenure, land rights, and farmer investment incentives in China. Agricultural Economics 19 (1-2), 63-71.

33. Li, L.C., 2010. Central-local relations in the People's Republic of China: trends, processes and impacts for policy implementation. Public Administration and Development 30 (3), 177-190.

34. Lin, J.Y.F., 1989. An economic-theory of institutional change - induced and imposed change. Cato Journal 9 (1), 1-33.

35. Lin, J.Y.F., 1992. Rural reforms and agricultural growth in China. American Economic Review 82 (1), 34-51.

36. Lin, J.Y.F., and Nugent, J. B., 1995, Chap 38 Institutions and economic development, in Behrman J. and Srinivasan T.N. (eds.) Handbook of Development Economics, Vol. III, Elsevier Science B. V., 1995.

37. Liu, S.Y., Carter, M.R., Yao, Y., 1998. Dimensions and diversity of property rights in rural China: dilemmas on the road to further reform. World Development 26 (10), 1789-1806.

38. Meramveliotakis, G., Milonakis, D., 2010. Surveying the transaction cost foundations of New Institutional Economics: A critical inquiry. Journal of Economic Issues 44, 1045-1071.

39. Montinola, G., Qian, Y., Weingast, B.R., 1995. Federalism, Chinese style: the political basis for economic success in China. World Politics 48 (1), 50-81.

40. National Bureau of Statistics of China, 2014. Statistical Communiqué of the People's Republic of China on the 2013 National Economic and Social Development. February 24, 2014. http://www.stats.gov.cn/english/PressRelease/201402/t20140224_515103.html.

41. Nolan, P., 1983. De-collectivization of agriculture in China, 1979-82: a long-term perspective. Cambridge Journal of Economics 7 (3-4), 381-403.

42. North, D.C., 1981. Structure and change in economic history. Norton, New York; 
London.

43. North, D.C., 1990. Institutions, institutional change and economic performance. Cambridge University Press, Cambridge.

44. North, D.C., Thomas, R.P., 1973. The rise of the Western world: a new economic history. University Press, Cambridge Eng.

45. Peng, X.Z., 2011. China's demographic history and future challenges. Science 333 (6042), 581-587.

46. Ruttan, V.W., Hayami, Y., 1984. Toward a theory of induced institutional innovation. Journal of Development Studies 20 (4), 203-223.

47. Saint-Macary, C., Keil A., Zeller M., Heidhues F., Dung P.T.M., 2010. Land titling policy and soil conservation in the northern plands of Vietnam. Land Use Policy 27 (2), 617-627.

48. Schultz, T.W., 1964. Transforming traditional agriculture. Yale University Press, New Haven.

49. Smith, G., 2013. Measurement, promotions and patterns of behavior in Chinese local government. Journal of Peasant Studies 40, 1027-1050.

50. Tversky, A., Kahneman, D., 1991. Loss aversion in riskless choice - A reference-dependent model. Quarterly Journal of Economics 106 (4), 1039-1061.

51. van de Kaa, E.J., 2010. Prospect theory and choice behaviour strategies: review and synthesis of concepts from social and transport sciences. European Journal of Transport and Infrastructure Research 10 (4), 299-329.

52. Wang, H., Tong, J.E., Su, F.B., Wei, G.X., Tao, R., 2011. To reallocate or not: reconsidering the dilemma in China's agricultural land tenure policy. Land Use Policy 28 (4), 805-814.

53. Williamson, Q.E., 2000. The new institutional economics: Taking stock, looking ahead. Journal of Economic Literature 38, 595-613.

54. Wilson, R.K., 2011. The contribution of behavioral economics to political science, in: Levi, M., Jackman, S., Rosenblum, N. (Eds.), Annual Review of Political Science, Vol. 14, pp. 201-223.

55. Wooldridge, J.M., 2010. Econometric analysis of cross section and panel data, 2nd ed. MIT, Cambridge, Mass.; London.

56. Xu, C.G., 2011. The fundamental institutions of China's reforms and development. Journal of Economic Literature 49 (4), 1076-1151.

57. Yao, Y., 2004a. Land tenure choice in Chinese villages: the rational versus the political model. Land Economics 80 (4), 477-489.

58. Yao, Y., 2004b. Political process and efficient institutional change. Journal of Institutional and Theoretical Economics 160 (3), 439-453.

59. Zhang, Y.J., 2012. A view from behavioral political economy on China's institutional change. China Economic Review 23 (4), 991-1002.

60. Zhu, X.D., 2012. Understanding China's growth: past, present, and future. Journal of Economic Perspectives 26 (4), 103-124.

\section{Acknowledgments}

The authors are grateful for the financial supports from the National Natural Science Foundation of China (Project \#71173226) and the Project of "985" in China. We are also in debt to Jianping Ye and Keliang Zhu for the survey data and the two anonymous referees for their useful and stimulating comments. 